\title{
IS 3 WEEKS OF EXERCISE ENOUGH TO CHANGE BLOOD PRESSURE AND CARDIAC REDOX STATE IN HYPERTENSIVE RATS?
}

\author{
Biljana Jakovljevic ${ }^{1}$, Sasa Plecevic ${ }^{2}$, Anica Petkovic ${ }^{3}$, Tamara Nikolic Turnic ${ }^{3}$, Isidora Milosavljevic ${ }^{3}$, Kristina Radoman $^{4}$ and Ivan Srejovic ${ }^{5}$ \\ ${ }^{1}$ College of Health Sciences, Zemun, Belgrade, Serbia \\ ${ }^{2}$ Sports Medicine Association of Serbia, Belgrade, Serbia \\ ${ }^{3}$ University of Kragujevac, Faculty of Medical Sciences, Department of Pharmacy, Kragujevac, Serbia \\ ${ }^{4}$ College of Health Studies, Podgorica, Montenegro \\ ${ }^{5}$ University of Kragujevac, Faculty of Medical Sciences, Department of Physiology, Kragujevac, Serbia
}

\author{
DA LI JE 3 NEDELJE VEŽBANJA DOVOLJNO DA PROMENI KRVNI \\ PRITISAK I SRČANI REDOKS STATUS KOD HIPERTENZIVNIH PACOVA? \\ Biljana Jakovljevići ${ }^{\text {, Saša Plečević }}{ }^{2}$, Anica Petković ${ }^{3}$, Tamara Nikolić Turnic ${ }^{3}$, Isidora Milosavljevićs ${ }^{3}$ Kristina Radoman $^{4}$ i Ivan Srejović $^{5}$ \\ ${ }^{1}$ Visoka medicinska škola strukovnih studija, Zemun, Beograd \\ ${ }^{2}$ Udruženje za medicinu sporta Srbije, Beograd, Srbija \\ ${ }^{3}$ Univerzitet u Kragujevcu, Fakultet medicinskih nauka, Katedra za farmaciju, Kragujevac, Srbija \\ ${ }^{4}$ Visa medicinska skola, Podgorica, Crna Gora \\ ${ }^{5}$ Univerzitet u Kragujevcu, Fakultet medicinskih nauka, Katedra za fiziologiju, Kragujevac, Srbija
}

Received / Primljen: 20. 09. 2017.

Accepted / Prihvaćen: 26. 09. 2017.

\begin{abstract}
The investigation was aimed to evaluate the effects of 3-weeks swimming exercise on blood pressure and redox status in high-salt-induced hypertensive rats. Male Wistar albino rats ( $n=40,6$ weeks old) were divided into 4 groups: 1. hypertensive rats that swam for 3 weeks; 2. sedentary hypertensive control rats; 3 . normotensive rats that swam for 3 weeks; 4. sedentary normotensive control rats. Hypertensive animals were on high concentrated sodium (8\% $\mathrm{NaCl}$ ) solution for 4 weeks (period of induction of hypertension). After sacrificing, hearts were isolated and perfused according to Langendorff technique at gradually increased coronary perfusion pressure from 40-120 $\mathrm{cmH}_{2} \mathrm{O}$. The oxidative stress markers were determined in coronary venous effluent: the index of lipid peroxidation (measured as TBARS), nitrites $\left(\mathrm{NO}_{2}^{-}\right)$, superoxide anion radical $\left(\mathrm{O}_{2}^{-}\right)$and hydrogen peroxide $\left(\mathrm{H}_{2} \mathrm{O}_{2}\right)$. Swimming did not lead to significant changes in levels of TBARS, $\mathrm{NO}_{2}^{-}, \mathrm{O}_{2}^{-}$in any of compared groups while levels of $\mathrm{H}_{2} \mathrm{O}_{2}$ were significantly higher in swimming hypertensive group comparing to swimming normotensive group at coronary perfusion pressure of $80-120 \mathrm{cmH}_{2} \mathrm{O}$. Our results indicate that the short-term swimming start to reduce blood pressure. In addition it seems that this type of swimming duration does not promote cardiac oxidative stress damages.
\end{abstract} heart

Keywords: hypertension, oxidative stress, swimming, rat
Studija je imala za cilj da ispita uticaj plivanja od tri nedelje na krvni pritisak i redoks status kod pacova sa hipertenzijom izazvanom visokim unosom soli. Muški Wistar albino pacovi ( $n=40,6$ nedelja starosti) su podeljeni u 4 grupe: 1. hipertenzivni pacovi koji su plivali 3 nedelje; 2. sedentarni hipertenzivni kontrolni pacovi; 3. normotenzivni pacovi koji su plivali 3 nedelje; 4. sedentarni normotenzivni kontrolni pacovi. Hipertenzivne životinje su 4 nedelje pile visoko koncentrovani rastvor natrijuma ( $8 \% \mathrm{NaCl}$ ). Nakon žrtvovanja, srca su izolovana i perfundovana prema Langendorff-ovoj tehnici pri rastućem koronarnom perfuzionom pritisku od 40-120 $\mathrm{cmH}_{2}$ O. Parametri oksidativnog stresa su određivani u koronarnom venskom efluentu indeks lipidne peroksidacije (meren kao TBARS), nitriti $\left(\mathrm{NO}_{2}^{-}\right)$, superoksid anjon radikal $\left(\mathrm{O}_{2}^{-}\right)$i hidrogen peroksid $\left(\mathrm{H}_{2} \mathrm{O}_{2}\right)$. Plivanje nije dovelo do značajnih promena u nivoima TBARS, $\mathrm{NO}_{2}$, $\mathrm{O}_{2}^{-}$ni u jednoj od poređenih grupa dok su nivoi $\mathrm{H}_{2} \mathrm{O}_{2}$ bili značajno veći u grupi hipertenzivnih pacova koja je plivala u poređenju sa grupom normotenzivnih pacova koja je plivala pri vrednostima koronarnog perfuzionog pritiska od 80-120 $\mathrm{cmH}_{2} \mathrm{O}$. Naši rezultati ukazuju da kratak period plivanja počinje da snižava krvni pritisak. Osim toga, čini se da ovaj tip plivanja ne podstiče srčana oštećenja oksidativnim stresom.

Ključne reči: hipertenzija, oksidativni stres, plivanje, srce pacova 


\section{INTRODUCTION}

Environmental factors, such as psychological stress, exercise, and dietary sodium intake, have long been considered relevant to both the etiology and control of human essential hypertension. Reduction in the stresses of everyday life, increased levels of exercise, and reduced dietary sodium intake have been recommend as having a beneficial effect in controlling arterial blood pressure. Similarly, high levels of life stress, sedentary lifestyle, and high dietary sodium intake have frequently been linked to cardiovascular diseases $(1,2)$. Hypertension is considered to be major risk factor for coronary heart diseases contributing to morbidity and mortality worldwide. Importantly, experimental animal studies clearly demonstrate a well-documented promotion of endothelial dysfunction in hypertension by production of oxidative stress markers $(3,4)$. This occurs due to imbalance between reactive oxygen species (ROS) and antioxidant capacity in favour of oxidants (5). Therefore, treatment of hypertension can be focused on oxidative stress as a possible target.

Regular physical exercise has been considered an effective method which can perform a multitude of beneficial effects for health, such as promotion of health and lifespan, betterment of quality of life and reduce the incidence of disease (6). In addition it has been published in some papers that physical exercise lowers blood pressure (BP) patients with essential hypertension (7) and in male spontaneously hypertensive rats (SHR) $(8,9)$. Interestingly, controversial effects were determined in female SHR (10). Although the antihypertensive mechanisms of exercise are not completely understood yet, numerous mechanisms are supposed to be involved in reduction of BP while exercising such as decrease in levels of angiotensin II and melioration of nitric oxide (NO) production (11), higher concentration of the plasmatic atrial natriuretic peptide (8), lower production of oxidative stress markers (12). Changes in redox status caused by swimming represent modification in an antioxidant enzyme, alters muscle gene expression thus contributing to exercise-induced adaptations to skeletal muscle. However, it should be taken into consideration that various factors influence the oxidative stress response to swimming training, such as type of exercise, intensity, duration, gender and age of athletes etc (13). Physical exercise may be of potential importance for prevention or treatment of hypertension or hypertension-associated pat.

In recent years there are increased interest on effects of short time physical load on cardiovascular system. Therefore, the objective of this investigation was to explore effects of short-term exercise training on $\mathrm{BP}$ and oxidative stress parameters in a rat model of high-salt-induced hypertension.

\section{MATERIAL AND METHODS}

\section{Ethical approval}

The study was performed in the laboratory for the cardiovascular physiology of the Faculty of Medical Sciences,
University of Kragujevac, Serbia. It was approved by Ethical committee of the Faculty, and performed according to the Faculty's rules for the welfare of laboratory animals, which are in consent with Good laboratory practice and European Council Directive (86/609/EEC).

\section{Animals and high-salt-induction of hypertension}

Forty male Wistar albino rats, body weight between 180 and $200 \mathrm{~g}$ (at the beginning of the experiment), six weeks old (obtained from the Military Medical Academy, Belgrade, Serbia) were housed under controlled environmental conditions, with a temperature of $22 \pm 2{ }^{\circ} \mathrm{C}$ and a 12-h light/dark cycle. The rats had ad libitum access to food and tap water or $\mathrm{NaCl}$ soluted in water (8\% solution).

At 6 weeks old rats were randomly divided into the following groups (10 animals per group):

1. hypertensive rats that swam for 3 weeks (S-HTA-3);

2. sedentery hypertensive control rats (HTA-3);

3. normotensive rats that swam for 3 weeks (S-NTA-3);

4. sedentery normotensive control rats (NTA-3).

Hypertensive animals were on high sodium $(8 \% \mathrm{NaCl}$ solution) diet for 4 weeks (period of induction hypertension), and this animals did not drink tap water during the experimental protocol.

BP was monitored before (initial values), after period of induction hypertension (confirmation of hypertension) and after the training period (assessment of the impact of swimming on hypertension).

\section{Swimming training protocol}

Rats swam in a specially constructed swimming pool made of glass $(80 \times 60 \times 100 \mathrm{~cm})$ in which water temperature $\left(37 \pm 1{ }^{\circ} \mathrm{C}\right)$ was maintained by an electric heater, and a pump continuously made waves in order to prevent rats from floating. The training protocol was conducted during the same period of the day $(8: 00-10: 00 \mathrm{am})$ for all the training sessions. The first week consisted of an adaptation period, initiated with 10 min of continuous swimming training on the first day. Swimming time was increased daily until reaching $60 \mathrm{~min}$ at the end of the fifth day. From the second week, the exercise duration was kept constant (60 min/day, 5 days/week) with 2 days of rest. Rats from the control group were put in water for 1 min a day, 5 days a week, in order to achieve the water-induced stress effect. This was maintained until the end of the training period, which lasted 3 weeks. To avoid effects related to acute exercise, animals rested for $48 \mathrm{~h}$ before being sacrificed for all additional procedures. The swimming was continuously supervised. Body weight was monitored weekly.

\section{Hemodynamic parameters determination}

Systolic BP (SBP), diastolic BP (DBP), mean arterial pressure (MAP) and heart rate (HR) were evaluated in conscious rats before and after period of induction of hypertension and after the training or sedentary period and was determined by an indirect tail-cuff method (IITC Life 
Science, Inc., USA). Animals were restrained for 5-10 min and conditioned to the procedure with cuff inflation-deflation cycles. The results of three stable measurements of BP were averaged.

\section{Isolated rat heart preparation}

The hearts of male Wistar albino rats $(\mathrm{n}=40,10$ in each experimental subgroup) were excised and retrogradely perfused according to Langendorff technique (Experimetria Ltd,1062 Budapest, Hungary). After a short-term narcosis induced by intraperitoneal application of ketamine (10 mg/kg) and xylazine (5 mg/kg), animals were sacrificed by cervical dislocation (Schedule 1 of the Animals/ Scientific Procedures, Act 1986, UK), and premedicated with heparin as an anticoagulant. After emergency thoracotomy and rapid cardiac arrest by superfusion with icecold isotonic saline, hearts were rapidly excised, the aortas were cannulated and retrogradely perfused at gradually increased coronary perfusion pressure (CPP) from 40 to $120 \mathrm{cmH}_{2} \mathrm{O}$ in order to establish coronary autoregulation.

The composition of the non-recirculating KrebsHenseleit perfusate was as follows $(\mathrm{mM}): \mathrm{NaCl} 118, \mathrm{KCI}$ 4.7, $\mathrm{CaCl}_{2} \times 2 \mathrm{H}_{2} \mathrm{O} 2.5, \mathrm{MgSO}_{4} \times 7 \mathrm{H}_{2} \mathrm{O} 1.7, \mathrm{NaHCO}_{3} 25, \mathrm{KH}-$ ${ }_{2} \mathrm{PO}_{4} 1.2$, glucose 11 , pyruvate 2 , equilibrated with $95 \% \mathrm{O}_{2}$ plus $5 \% \mathrm{CO}_{2}$ and warmed to $37^{\circ} \mathrm{C}(\mathrm{pH} 7.4)$.

\section{Biochemical analysis}

Samples of coronary venous effluent were collected on each value of perfusion pressure $\left(40-120 \mathrm{cmH}_{2} \mathrm{O}\right)$. The following parameters of oxidative stress were determined spectrophotometrically (UV-1800 Shimadzu UV spectrophotometer, Japan): the levels of index of lipid peroxidation, measured as thiobarbituric acid-reactive substances (TBARS), nitrites $\left(\mathrm{NO}_{2}^{-}\right)$, superoxide anion radical $\left(\mathrm{O}_{2}^{-}\right)$ and hydrogen peroxide $\left(\mathrm{H}_{2} \mathrm{O}_{2}\right)$.

Determination of index of lipid peroxidation (TBARS)

The degree of lipid peroxidation in the coronary venous effluent was estimated by measuring TBARS, using 1 \% thiobarbituric acid in $0.05 \mathrm{NaOH}$, which was incubated with the coronary effluent at $100{ }^{\circ} \mathrm{C}$ for $15 \mathrm{~min}$ and measured at $530 \mathrm{~nm}$. Krebs-Henseleit solution was used as a blank probe (14).

\section{Determination of nitrites $\left(\mathrm{NO}_{2}^{-}\right)$}

Nitric oxide decomposes rapidly to form stable nitrite/ nitrate products. The nitrite level $\left(\mathrm{NO}_{2}{ }^{-}\right)$was measured and used as an index of nitric oxide (NO) production, using Griess's reagent. A total of $0.5 \mathrm{ml}$ of perfusate was precipitated with $200 \mu \mathrm{l}$ of $30 \%$ sulpho-salicylic acid, vortexed for $30 \mathrm{~min}$, and centrifuged at $3000 \mathrm{x}$ g. Equal volumes of the supernatant and Griess's reagent, containing $1 \%$ sulphanilamide in $5 \%$ phosphoric acid $/ 0.1 \%$ naphthalene ethylenediaminedihydrochloride were added and incubated for $10 \mathrm{~min}$ in the dark and measured at $543 \mathrm{~nm}$. The nitrite levels were calculated using sodium nitrite as the standard (15).

\section{Determination of hydrogen peroxide $\left(\mathrm{H}_{2} \mathrm{O}_{2}\right)$}

The measurement of the level of hydrogen peroxide $\left(\mathrm{H}_{2} \mathrm{O}_{2}\right)$ was based on the oxidation of phenol red by hydrogen peroxide in a reaction catalyzed by horseradish peroxidase (HRPO). Two hundred microliters of perfusate was precipitated using $800 \mathrm{ml}$ of freshly prepared phenol red solution; $10 \mu \mathrm{l}$ of (1:20) HRPO (made ex tempore) was subsequently added. For the blank probe, an adequate volume of Krebs-Henseleit solution was used instead of coronary venous effluent. The level of $\mathrm{H}_{2} \mathrm{O}_{2}$ was measured at 610 $\mathrm{nm}(16)$

\section{Determination of superoxide anion radical $\left(\mathrm{O}_{2}^{-}\right)$}

The level of the superoxide anion radical $\left(\mathrm{O}_{2}^{-}\right)$was measured via a nitro blue tetrazolium (NBT) reaction in TRIS buffer with coronary venous effluent, at $530 \mathrm{~nm}$. Krebs-Henseleit solution was used as a blank probe (17).

\section{Statistical analysis}

Complete statistical evaluation was performed with SPSS Statistics 18. Normality of parameter distribution was checked with the Kolmogorov-Smirnov test. MannWhitney $U$ test was used for comparison of groups. Statistic $p$ values less than 0.05 were considered to be statistically significant.

\section{RESULTS}

\section{Body weight weight}

The mean values of body weight of S-HTA-3 and SNTA-3 rats and their controls did not significantly differ throughout the first week of research, while the values of body weight of S-HTA-3 compared to S-NTA-3 rats were

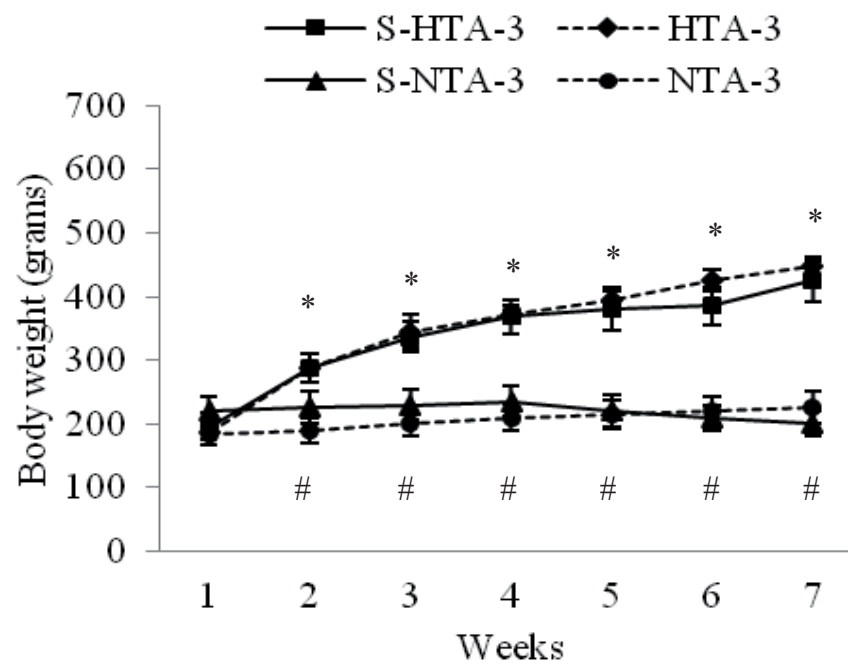

Fig. 1 - Mean body weight of hypertensive and normotensive rats. The values are represented as mean \pm SD. S-HTA-3- hypertensive rats that swam for 3 weeks; HTA-3-sedentery hypertensive control rats; S-NTA-3normotensive rats that swam for 3 weeks; NTA-3-sedentery normotensive control rats. * statistical significance between S-HTA-3 vs S-NTA-3; \# statistical significance between HTA-3 vs NTA-3. 
Table 1. The average values of hemodynamic parameters of hypertensive and normotensive rats that swam for three weeks and their controls in last week

\begin{tabular}{|c|c|c|c|c|}
\hline \multirow{2}{*}{ Groups } & \multicolumn{4}{|c|}{ Hemodynamic parameters } \\
\cline { 2 - 5 } & SBP $(\mathrm{mmHg})$ & DBP $(\mathrm{mmHg})$ & MAP $(\mathrm{mmHg})$ \\
\hline S-HTA-3 & $196,37 \pm 6,87 \mathrm{a}, \mathrm{b}$ & $104,31 \pm 7,12^{\mathrm{a}, \mathrm{b}}$ & $137,68 \pm 6,64$ a,b & $330,19 \pm 19,27$ \\
\hline HTA-3 & $205,69 \pm 7,19$ & $115,81 \pm 8,73$ & $142,23 \pm 7,12$ & $325,17 \pm 14,37$ \\
\hline S-NTA-3 & $120,01 \pm 4,27$ & $80,18 \pm 6,45$ & $32,03 \pm 6,75$ & $96,13 \pm 4,27$ \\
\hline NTA-3 & $123,98 \pm 6,15$ & $83,23 \pm 7,65$ & $327,48 \pm 16,57$ & $3,28 \pm 17,21$ \\
\hline
\end{tabular}

Data are means \pm SD. SBP, systolic pressure; DBP, diastolic pressure; MAP, mean arterial pressure; HR, heart rate. Statistical significance was considered for a $p$ value less than 0.05 (" $p<0.05)$; ${ }^{\mathrm{a}} p<0.05$ - S-HTA-3 vs. HTA-3; ${ }^{\mathrm{b}} p<0.05$ - S-HTA-3 vs. S-NTA-3; S-HTA-3- hypertensive rats that swam for 3 weeks; HTA-3-sedentery hypertensive control rats; S-NTA-3-normotensive rats that swam for 3 weeks; NTA-3-sedentery normotensive control rats.

significantly higher from the second week to the end of the study (II week - $\mathrm{p}=0.043$; III week - $\mathrm{p}=0.033$; IV week - $\mathrm{p}$ $=0.028$; week $-\mathrm{p}=0.028$; VI week $-\mathrm{p}=0.028$; VII week $-\mathrm{p}$ $=0.011)$. The mean values of body weight of hypertensive controls compared to normotensive controls were significantly higher from the second week to the end of the study (II week - $\mathrm{p}=0.033$; III week $-\mathrm{p}=0.023$; IV week $-\mathrm{p}=$ 0.018; V week - $\mathrm{p}=0.018$; VI week - $\mathrm{p}=0.008$; VII week - $\mathrm{p}$ $=0.008)($ Figure 1).

\section{Hemodynamic parameters}

Initial levels of BP (period of induction of hypertension) were not different between the groups (average value $115.58 / 82.340 \pm 8.14 / 5.18)$. After 4 weeks of treatment with high salt water, hypertension was confirmed in hypertensive groups $(198.85 / 114 \pm 9.31 / 6.23)$. There was significant differences between HTA-3 and S-HTA-3 group in values of SBP, DBP, MAP. The value of pressures (SBP, DBP, MAP) in S-HTA-3 rats were significantly higher compared with S-NTA rats, while there were no difference in values of HR between groups (Table 1).

\section{Oxidative stress parameters}

Parameters of oxidative stress in coronary effluent at different coronary perfusion pressures in swimming and sedentary hypertensive and normotensive rats are shown in Figures 2-5, statistical significance is presented in Table 2.

There were no significant differences in values of TBARS, $\mathrm{NO}_{2}^{-}$and $\mathrm{O}_{2}^{-}$between the groups (swimming vs sedentary and normotensive vs hypertensive) (Figures 2-4).

Comparing S-HTA-3 and S-NTA-3 with sedentary groups significant changes was not observed in values of $\mathrm{H}_{2} \mathrm{O}_{2}$ (Figure 5). Significantly higher levels of $\mathrm{H}_{2} \mathrm{O}_{2}$ was noticed in S-HTA-3 group comparing to S-NTA-3 group at CPPs $\left(80 \mathrm{cmH}_{2} \mathrm{O}-\mathrm{p}=0.049,100 \mathrm{cmH}_{2} \mathrm{O}-\mathrm{p}=0.037,120\right.$ $\left.\mathrm{cmH}_{2} \mathrm{O}-\mathrm{p}=0.029\right)$.

\section{DISCUSSION}

First research that was conducted in 1978, gave information about the association between exercise and oxidative stress (18). After many investigations in this field, it was

Table 2. Significance in level of oxidative stress parameters between hypertensive and normotensive rats who swam for three weeks at different values of coronary perfusion pressures

\begin{tabular}{|c|c|c|c|c|c|c|c|c|}
\hline \multirow{2}{*}{$\begin{array}{c}\mathrm{CPP} \\
\left(\mathrm{cmH}_{2} \mathrm{O}\right)\end{array}$} & \multicolumn{4}{|c|}{$\mathrm{O}_{2}^{-}(\mathrm{nmol} / \mathrm{min} / \mathrm{g} \mathrm{wt})$} & \multicolumn{4}{|c|}{$\mathrm{NO}(\mathrm{nmol} / \mathrm{min} / \mathrm{g} \mathrm{wt})$} \\
\hline & $\begin{array}{c}\text { S-HTA-3 vs. } \\
\text { HTA-3 }\end{array}$ & $\begin{array}{c}\text { S-NTA-3 vs. } \\
\text { NTA-3 }\end{array}$ & $\begin{array}{c}\text { S-HTA-3 vs. } \\
\text { S-NTA-3 }\end{array}$ & $\begin{array}{l}\text { HTA-3 vs. } \\
\text { NTA-3 }\end{array}$ & $\begin{array}{c}\text { S-HTA-3 vs. } \\
\text { HTA-3 }\end{array}$ & $\begin{array}{c}\text { S-NTA-3 vs. } \\
\text { NTA-3 }\end{array}$ & $\begin{array}{c}\text { S-HTA-3 vs. } \\
\text { S-NTA-3 }\end{array}$ & $\begin{array}{c}\text { HTA-3 vs } \\
\text { NTA-3 }\end{array}$ \\
\hline 40 & $\mathrm{p}>0,050$ & $\mathrm{p}>0,050$ & $\mathrm{p}>0,050$ & $\mathrm{p}>0,050$ & $\mathrm{p}>0,050$ & $\mathrm{p}>0,050$ & $\mathrm{p}>0,050$ & $\mathrm{p}>0,050$ \\
\hline 60 & $\mathrm{p}>0,050$ & $\mathrm{p}>0,050$ & $\mathrm{p}>0,050$ & $\mathrm{p}>0,050$ & $\mathrm{p}>0,050$ & $\mathrm{p}>0,050$ & $\mathrm{p}>0,050$ & $\mathrm{p}>0,050$ \\
\hline 80 & $\mathrm{p}>0,050$ & $\mathrm{p}>0,050$ & $\mathrm{p}>0,050$ & $\mathrm{p}>0,050$ & $\mathrm{p}>0,050$ & $\mathrm{p}>0,050$ & $\mathrm{p}>0,050$ & $\mathrm{p}>0,050$ \\
\hline 100 & $\mathrm{p}>0,050$ & $\mathrm{p}>0,050$ & $\mathrm{p}>0,050$ & $\mathrm{p}>0,050$ & $\mathrm{p}>0,050$ & $\mathrm{p}>0,050$ & $\mathrm{p}>0,050$ & $\mathrm{p}>0,050$ \\
\hline \multirow[t]{3}{*}{120} & $\mathrm{p}>0,050$ & $\mathrm{p}>0,050$ & $\mathrm{p}>0,050$ & $\mathrm{p}>0,050$ & $\mathrm{p}>0,050$ & $\mathrm{p}>0,050$ & $\mathrm{p}>0,050$ & $\mathrm{p}>0,050$ \\
\hline & \multicolumn{4}{|c|}{$\mathrm{H}_{2} \mathrm{O}_{2}(\mathrm{nmol} / \mathrm{min} / \mathrm{g} \mathrm{wt})$} & \multicolumn{4}{|c|}{$\mathrm{TBARS}(\mu \mathrm{mol} / \mathrm{min} / \mathrm{g} w \mathrm{t})$} \\
\hline & $\begin{array}{c}\text { S-HTA-3 vs. } \\
\text { HTA-3 }\end{array}$ & $\begin{array}{c}\text { S-NTA-3 vs. } \\
\text { NTA-3 }\end{array}$ & $\begin{array}{c}\text { S-HTA-3 vs. } \\
\text { S-NTA-3 }\end{array}$ & $\begin{array}{l}\text { HTA-3 vs. } \\
\text { NTA-3 }\end{array}$ & $\begin{array}{c}\text { S-HTA-3 vs. } \\
\text { HTA-3 }\end{array}$ & $\begin{array}{c}\text { S-NTA-3 vs. } \\
\text { NTA-3 }\end{array}$ & $\begin{array}{c}\text { S-HTA-3 vs. } \\
\text { S-NTA-3 }\end{array}$ & $\begin{array}{c}\text { HTA-3 vs } \\
\text { NTA-3 }\end{array}$ \\
\hline 40 & $\mathrm{p}>0,050$ & $\mathrm{p}>0,050$ & $\mathrm{p}>0,050$ & $\mathrm{p}>0,050$ & $\mathrm{p}>0,050$ & $\mathrm{p}>0,050$ & $\mathrm{p}>0,050$ & $\mathrm{p}>0,050$ \\
\hline 60 & $\mathrm{p}>0,050$ & $\mathrm{p}>0,050$ & $\mathrm{p}>0,050$ & $\mathrm{p}>0,050$ & $\mathrm{p}>0,050$ & $\mathrm{p}>0,050$ & $\mathrm{p}>0,050$ & $\mathrm{p}>0,050$ \\
\hline 80 & $\mathrm{p}>0,050$ & $\mathrm{p}>0,050$ & $\mathrm{p}=0,049$ & $\mathrm{p}>0,050$ & $\mathrm{p}>0,050$ & $\mathrm{p}>0,050$ & $\mathrm{p}>0,050$ & $\mathrm{p}>0,050$ \\
\hline 100 & $\mathrm{p}>0,050$ & $\mathrm{p}>0,050$ & $\mathrm{p}=\mathbf{0 , 0 3 7}$ & $\mathrm{p}>0,050$ & $\mathrm{p}>0,050$ & $\mathrm{p}>0,050$ & $\mathrm{p}>0,050$ & $\mathrm{p}>0,050$ \\
\hline 120 & $\mathrm{p}>0,050$ & $\mathrm{p}>0,050$ & $\mathrm{p}=0,029$ & $\mathrm{p}>0,050$ & $\mathrm{p}>0,050$ & $\mathrm{p}>0,050$ & $\mathrm{p}>0,050$ & $\mathrm{p}>0,050$ \\
\hline
\end{tabular}

S-HTA-3- hypertensive rats that swam for 3 weeks; HTA-3-sedentery hypertensive control rats; S-NTA-3- normotensive rats that swam for 3 weeks; NTA-3-sedentery normotensive control rats. 

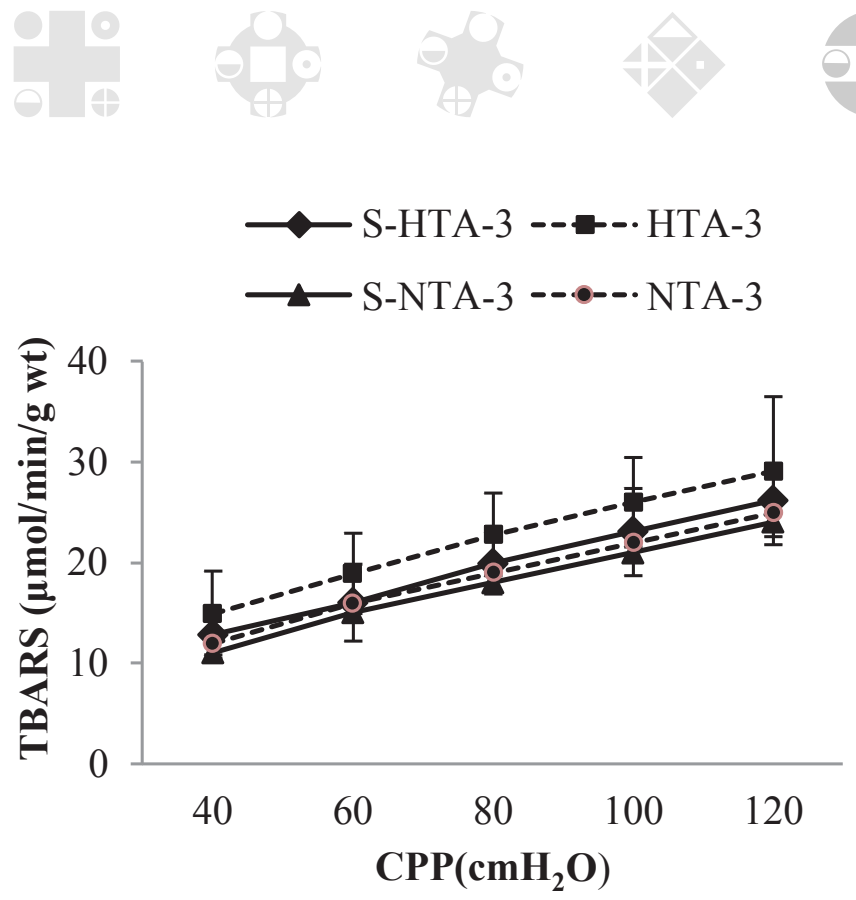

Fig. 2- Effects of 3 weeks of swimming on TBARS levels of hyperten sive and normotensive rats. The values are represented as mean $\pm \mathrm{SD}$. S-HTA-3- hypertensive rats that swam for 3 weeks; HTA-3-sedentery hypertensive control rats; S-NTA-3- normotensive rats that swam for 3 weeks; NTA-3-sedentery normotensive control rats. "statistical significance at the level of $\mathrm{p}<0.05$ is shown in Table 2 .
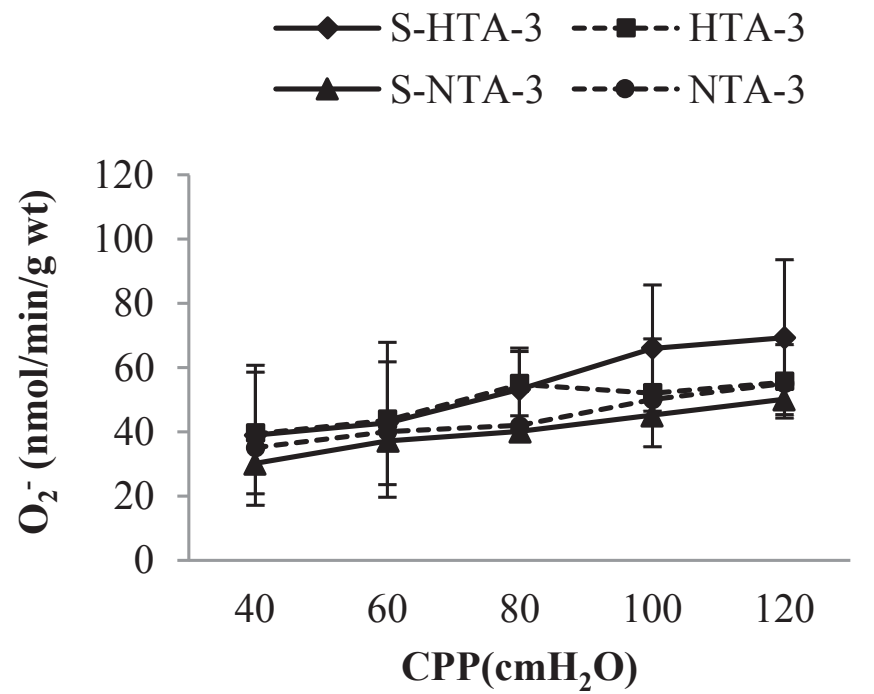

Fig. 4- Effects of 3 weeks of swimming on $\mathrm{O}_{2}^{-}$levels of hypertensive and normotensive rats. The values are represented as mean \pm SD. S-HTA-3hypertensive rats that swam for 3 weeks; HTA-3-sedentery hypertensive control rats; S-NTA-3- normotensive rats that swam for 3 weeks; NTA3 -sedentery normotensive control rats. "statistical significance at the level of $\mathrm{p}<0.05$ is shown in Table 2 .

described that increased aerobic meabolism is prospective sourse of oxidative stress during anaerobic exercise (19). Futrhermore, aerobic exercise has been shown to be effective in a significant reduction of ROS and in decrease of the occurrence of ROS associated diseases, including hypertension (20). Although many studies aimed to determine the influence of tredmill or cycle ergometer exercise on oxidative stress markers (21), our aim was to examine the effects of short-term swimming exercise considering that swimming has been proposed as a convenient model for

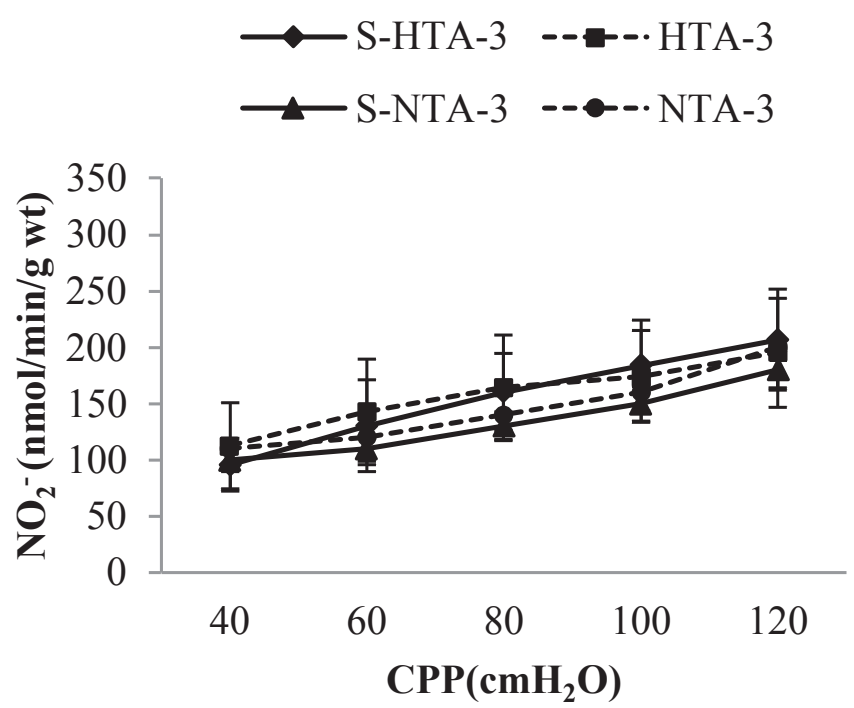

Fig. 3- Effects of 3 weeks of swimming on $\mathrm{NO}_{2}{ }^{-}$levels of hypertensive and normotensive rats. The values are represented as mean \pm SD. S-HTA-3hypertensive rats that swam for 3 weeks; HTA-3-sedentery hypertensive control rats; S-NTA-3- normotensive rats that swam for 3 weeks; NTA3 -sedentery normotensive control rats. "statistical significance at the level of $\mathrm{p}<0.05$ is shown in Table 2 .
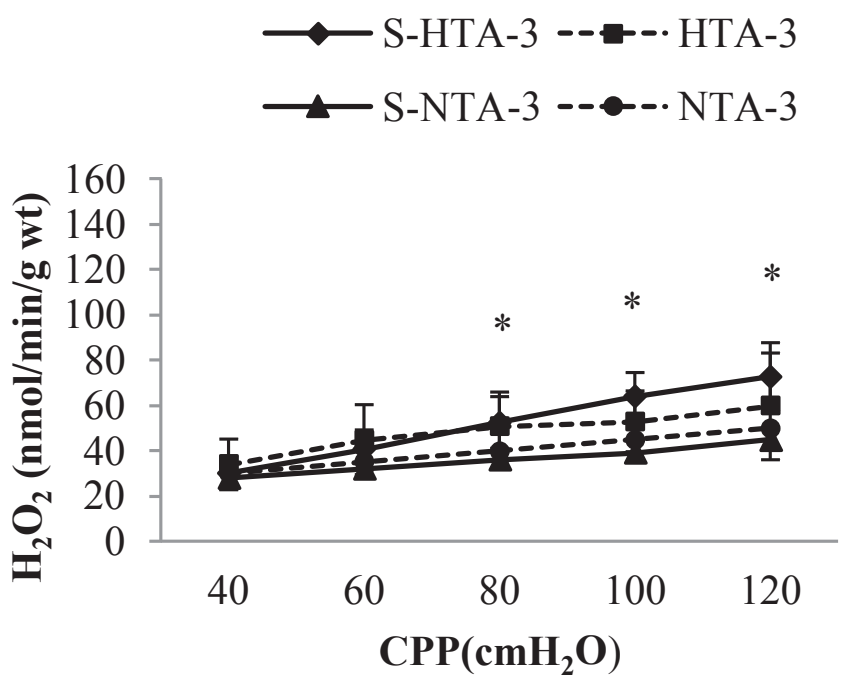

Fig. 5- Effects of 3 week of swimming on $\mathrm{H}_{2} \mathrm{O}_{2}$ levels of hypertensive and normotensive rats. The values are represented as mean \pm SD. S-HTA-3hypertensive rats that swam for 3 weeks; HTA-3-sedentery hypertensive control rats; S-NTA-3- normotensive rats that swam for 3 weeks; NTA3-sedentery normotensive control rats. "statistical significance at the level of $\mathrm{p}<0.05$ is shown in Table 2.

identifying the physiological, biochemical and molecular responses to acute exercise training and the adaptations to chronic exercise training $(22,23)$.

Due to the fact that numerous patients choose a nonweight-bearing physical activity such as swimming, it is important to determine if this kind of practice has potential antihypertensive effects (24). Regular physical activity contributed in reduction of elevated BP in hypertensive patients and hypertensive animals in which hypertension was induced by $\mathrm{N}(\omega)$-nitro-L-arginine methyl ester (L-NAME) 
$(25,26)$, deoxycorticosterone acetate (DOCA) (27) as well as in spontaneously hypertensive (28), Dahl saltsensitive and salt-resistant rats (29).

Taken together, these studies suggest the beneficial effects of aerobic training upon arterial blood pressure which seems to be intensity-dependent $(28,30)$. Our findings are in accordance with previous work that showed decrease in arterial pressure and MAP after four and eight weeks of a swimming program in spontaneously hypertensive rats (31-33). Nevertheless, it is important to recognize that even a $5-6 \mathrm{mmHg}$ decrease in arterial blood pressure which is similar to that observed in our study can be associated with a approximately $42 \%$ reduction in stroke incidence and a approximately $14 \%$ reduction in coronary heart disease as noted in several epidemiologic studies (34). Significant reduction of SBP, DBP and MAP in our study proved that swimming training can be prescribed to patients with hypertension as a non-pharmacological treatment. Reason for reduction of BP may be due to lower sympathetic activity induced by physical activity which can be a consequence of progression of arterial baroreflex and chemosensitive cardiopulmonary baroreflex sensitivity in SHR. In present study swimming also led to maintenance of body weight in hypertensive rats which certainly contributed to reduction of BP (35).

A link between hypertension and oxidative stress is well established. Redox imbalance, increased bioavailability of ROS or/and decreased antioxidant capacity has been demonstrated both in humans and animals (36). However the presence of oxidative stress within the myocardium have been very poorly investigated. Therefore we sought to assess the changes in cardiac oxidative stress parameters of hypertensive rats after short-term swimming or sedentary period.

Analysis of parameters that we determined in the coronary venous effluent during coronary autoregulation refers to the oxidative stress in the endocardium of the left ventricle. Our data have shown that values of pro-oxidant markers such as TBARS, $\mathrm{NO}_{2}^{-}, \mathrm{O}_{2}^{-}$were not affected by 3 weeks swimming protocol. According to Claudio et al excercise training prevented the increase of ROS production in ovariectomized hypertensive rats demonstrating increased expresion of antioxidative enzymes. Potential explanation for non excessive production of ROS besides above mentioned mechanism, may also be lower electron leakage from mitochondria or chronic exposure of tissue to ROS, induced by training, which makes the organ more resistant to the effects that derive from the mechanisms of oxidative stress (37).

On the other hand, investigation conducted on hypertensive rats trained 6 weeks showed that exercise lead to significant reduction of TBARS values in serum when compared to sedentary group. Also significant decrease of NO was noticed in sedentary hypertensive group but level of NO increased in trained hypertensive group (38). Furthermore, Bertagnolli and co-workers noticed similar changes in favor of lipid peroxidation in 10 weeks trained SHR group. These significant changes in ROS release may be due to longer duration of physical load (39).
Surprisingly, none of the researchers has not dealed with determination of $\mathrm{H}_{2} \mathrm{O}_{2}$ levels in hypertensive physicaly active subjects. We noticed that levels of $\mathrm{H}_{2} \mathrm{O}_{2}$ were significantly higher in S-HTA-3 group comparing to $\mathrm{S}$ NTA at CPP of 80-120 $\mathrm{cmH}_{2} \mathrm{O}$. Other researchers measured tissue total oxidant status (TOS) in heart tissue and expressed their results in terms of micromolar hydrogen peroxide equivalent per liter $\left(1 \mathrm{~mol} \mathrm{H}_{2} \mathrm{O}_{2}\right.$ equiv/L/mg protein). Their observation was that hypertensive animals had higher tissue oxidative stress levels than normotensives (40). Assumption for high concentration of hydrogen peroxide in hypertensive swimming rats may be activation of angiotensin II probably through angiotensin AT1 receptor-dependent stimulation of NADPH oxidase (Nox) enzymes (41).

On the basis of all mentioned above it can be assumed that the most important determinating factors of exrcise induced modification of cardiac oxidative stress can be duration and/or intensity.

\section{CONCLUSION}

Our results clearly indicate that reduction of BP may start after $3^{\text {rd }}$ week of training. In addition it seems that duration of three weeks of swimming does not promote cardiac oxidative stress damages. These findings could be one step closer for better understanding of short-time exercise on blood preassure and oxidative stress of the heart.

\section{ACKNOWLEDGMENTS}

This work was supported by Junior Project 01/2015, Faculty of Medical Sciences, University of Kragujevac, Serbia.

\section{REFERENCES}

1. Buttar HS, Li T, Ravi N. Prevention of cardiovascular diseases: Role of exercise, dietary interventions, obesity and smoking cessation. Exp Clin Cardiol. 2005; 10(4):229-49.

2. Gupta R, Guptha S. Strategies for initial management of hypertension. Indian J Med Res. 2010; 132:531-42. Review.

3. Cai, H. and Harrison, D.G., Endothelial dysfunction in cardiovascular diseases: the role of oxidant stress. Circ Res. 2000; 87(10): 840-844.

4. Montezano AC, Dulak-Lis M, Tsiropoulou S, Harvey A, Briones AM, Touyz RM. Oxidative stress human hypertension: vascular mechanisms, biomarkers, and novel therapies. Can J Cardiol. 2015; 31(5):631-41.

5. Birben E, Sahiner UM, Sackesen C, Erzurum S, Kalayci O. Oxidative stress and antioxidant defense. World Allergy Organ J. 2012;5(1):9-19. 
6. Vina J, Sanchis-Gomar F, Martinez-Bello V, Gomez-Cabrera MC. Exercise acts as a drug; the pharmacological benefits of exercise. Br J Pharmacol. 2012;167(1):1-12.

7. Higashi Y, Sasaki S, Sasaki N, Nakagawa K, Ueda T, Yoshimizu A, Kurisu S,Matsuura H, Kajiyama G, Oshima T. Daily aerobic exercise improves reactive hyperemia in patients with essential hypertension. Hypertension. 1999; 33:591-7.

8. Endlich PW, Firmes LB, Gonçalves WL, Gouvea SA, Moysés MR, Bissoli NS, Reis AM, Abreu GR. Involvement of the atrial natriuretic peptide in the reduction of arterial pressure induced by swimming but not by running training in hypertensive rats. Peptides. 2011; 32(8):1706-12.

9. Song YJ, Sawamura M, Ikeda K, Igawa S, Nara Y, Yamori Y. Training in swimming reduces blood pressure and increases muscle glucose transport activity as well as GLUT4 contents in stroke-prone spontaneously hypertensive rats. Appl Human Sci.1998; 17(6):275-80.

10. Coimbra R, Sanchez LS, Potenza JM, Rossoni LV, Amaral SL, Michelini LC. Is gender crucial for cardiovascular adjustments induced by exercise training in female spontaneously hypertensive rats? Hypertension. 2008; 52(3):514-21.

11. Kohno H, Furukawa S, Naito H, Minamitani K, Ohmori D, Yamakura F. Contribution of nitric oxide, angiotensin II and superoxide dismutase to exercise-induced attenuation of blood pressure elevation in spontaneously hypertensive rats. Jpn Heart J. 2002; 43(1):25-34.

12. Kimura H, Kon N, Furukawa S, Mukaida M, Yamakura F, Matsumoto K, Sone H,Murakami-Murofushi K. Effect of endurance exercise training on oxidative stress in spontaneously hypertensive rats (SHR) after emergence of hypertension. Clin Exp Hypertens. 2010; 32(7):407-15.

13. Ruzicic R. D., Jakovljevic V., Djordjevic D. Oxidative Stress in Training, Overtraining and Detraining: from Experimental to Applied Research. Ser J Exp Clin Res. 2016; 17(4): 343-348.

14. Ohkawa H, Ohishi N, Yagi K. Assay for lipid peroxides in animal tissues by thiobarbituric acid reaction. Anal Biochem 1979; 95(2):351-8.

15. Green LC, Wagner DA, Glogowski J, Skipper PL, Wishnok JS, Tannenbaum SR. Analysis of nitrate, nitrite, and $[15 N]$ nitrate in biological fluids. Anal Biochem 1982; 126(1):131-8.

16. Pick E, Keisari Y. A simple colorimetric method for the measurement of hydrogen peroxide produced by cells in culture. J Immunol Methods 1980; 38(1-2):161-70.

17. Auclair C, Voisin E. Nitroblue tetrazolium reduction. In: Greenvvald RA, ed. Handbook of Methods for Oxygen Radical Research. Boca Raton: CRC Press, 1985:123-32.

18. Dillard CJ, Litov RE, Savin WM, Dumelin EE, Tappel AL. Effects of exercise, vitamin E, and ozone on pulmonary function and lipid peroxidation. J Appl Physiol Respir Environ Exerc Physiol. 1978; 45(6):927-32.

19. Stanković M., Radovanović, D. Oxidative stress and physical activity. Sport Logia. 2012; 8:1-11.
20. Roque FR, Briones AM, García-Redondo AB, Galán M, Martínez-Revelles S, Avendaño MS, Cachofeiro V, Fernandes T, Vassallo DV, Oliveira EM, Salaices M. Aerobic exercise reduces oxidative stress and improves vascular changes of small mesenteric and coronary arteries in hypertension. Br J Pharmacol. 2013; 168(3):686-703.

21. Powers SK, Radak Z, Ji LL. Exercise-induced oxidative stress: past, present and future. J Physiol. 2016; 594(18):5081-92.

22. Araujo LC, de Souza IL, Vasconcelos LH, Brito Ade F, Queiroga FR, Silva AS, da Silva PM, Cavalcante Fde A, da Silva BA. Chronic aerobic swimming exercise promotes functional and morphological changes in rat ileum. Biosci Rep. 2015; 35(5).

23. Balcı SS, Pepe H. Effects of gender, endurance training and acute exhaustive exercise on oxidative stress in the heart and skeletal muscle of the rat. Chin J Physiol. 2012; 55(4):236-44.

24. Tanaka H, Bassett DR Jr, Howley ET, Thompson DL, Ashraf M, Rawson FL. Swimming training lowers the resting blood pressure in individuals with hypertension. J Hypertens. 1997; 15(6):651-7.

25. Husain K. Exercise conditioning attenuates the hypertensive effects of nitric oxide synthase inhibitor in rat. Mol Cell Biochem. 2002; 231(1-2):129-37.

26. Kuru O, Sentürk UK, Koçer G. Effect of exercise training on resistance arteries in rats with chronic NOS inhibition. J Appl Physiol 2009; 107: 896-902.

27. Fregly MJ. Effect of an exercise regimen on development of hypertension in rats. J Appl Physiol 1984; 56:381-387.

28. Véras-Silva AS, Mattos KC, Gava NS, Brum PC, Negrão CE, Krieger EM. Low-intensity exercise training decreases cardiac output and hypertension in spontaneously hypertensive rats. Am J Physiol. 1997; 273:H2627-31.

29. Shepherd RE, Kuehne ML, Kenno KA. Attenuation of blood pressure increases in Dahl salt-sensitive rats by exercise. J Appl Physiol 1982; 52:1608-1613.

30. Libonati JR, Sabri A, Xiao C, Macdonnell SM, Renna BF. Exercise training improves systolic function in hypertensive myocardium. J Appl Physiol (1985).2011; 111(6):1637-43.

31. Endlich PW, Firmes LB, Gonçalves WL, Gouvea SA, Moysés MR, Bissoli NS, Reis AM, Abreu GR. Involvement of the atrial natriuretic peptide in the reduction of arterial pressure induced by swimming but not by running training in hypertensive rats. Peptides. 2011; 32(8):1706-12.

32. Goessler KF, Martins-Pinge MC, da Cunha NV, KarlenAmarante M, de Andrade FG, Polito MD. Direct renin inhibitor therapy and swimming training: hemodynamic and cardiac effects in hypertensive and normotensive rats. Clin Exp Hypertens.2015; 37(4):345-52.

33. Totou NL, Sá RWM, Alzamora AC, Cardoso LM, Becker LK.Cardiopulmonary Reflex and Blood Pressure Response after Swimming and Treadmill Exercisein Hypertensive Rats. JEPonline. 2015; 18(5):86-95. 
34. Collins R, Peto R, MacMahon S, Hebert P, Fiebach $\mathrm{NH}$, Eberlein KA, Godwin J,Qizilbash N, Taylor JO, Hennekens $\mathrm{CH}$. Blood pressure, stroke, and coronary heart disease: part 2, short-term reductions in blood pressure: overview of randomized drug trials in their epidemiological context. Lancet. 1990. 335(8693):827-838.

35. Zamo FS, Barauna VG, Chiavegatto S, Irigoyen MC, Oliveira EM. The renin-angiotensin system is modulated by swimming training depending on the age of spontaneously hypertensive rats. Life Sci. 2011; 89(3-4):93-9.

36. Korsager Larsen M, Matchkov VV. Hypertension and physical exercise: The role of oxidative stress. Medicina (Kaunas). 2016; 52(1):19-27.

37. Claudio ER, Almeida SA, Mengal V, Brasil GA, Santuzzi CH, Tiradentes RV,Gouvea SA, Bissoli NS, Santos RL, Abreu GR. Swimming training prevents coronary endothelial dysfunction in ovariectomized spontaneously hypertensive rats. Braz J Med Biol Res. 2017; 50(1):e5495.

38. Cardoso AM, Martins CC, Fiorin Fda S, Schmatz R, Abdalla FH, Gutierres J,Zanini D, Fiorenza AM, Ste- fanello N, Serres JD, Carvalho F, Castro VP, Mazzanti CM, Royes LF, Belló-Klein A, Goularte JF, Morsch VM, Bagatini MD, Schetinger MR. Physical training prevents oxidative stress in L-NAME-induced hypertension rats. Cell Biochem Funct. 2013; 31(2):136-51.

39. Goto C, Higashi Y, Kimura M, Noma K, Hara K, Nakagawa K, Kawamura M, Chayama K, Yoshizumi M, Nara I. Effect of different intensities of exercise on endothelium-dependent vasodilation in humans: role of endothelium-dependent nitric oxide and oxidative stress. Circulation. 2003; 108(5):530-5.

40. Kilic-Erkek O, Kilic-Toprak E, Caliskan S, Ekbic Y, Akbudak IH, Kucukatay V,Bor-Kucukatay M. Detraining reverses exercise-induced improvement in blood pressure associated with decrements of oxidative stress in various tissues in spontaneously hypertensive rats. Mol Cell Biochem. 2016;412(1-2):209-19.

41. Sousa T, Oliveira S, Afonso J, Morato M, Patinha D, Fraga S, Carvalho F,Albino-Teixeira A. Role of $\mathrm{H}(2)$ $\mathrm{O}(2)$ in hypertension, renin-angiotensin system activation and renal medullary disfunction caused by angiotensin II. Br J Pharmacol. 2012; 166(8):2386-401. 